\title{
Quality properties of doughs and noodles using chayotextle (Sechiem edule) flours
}

\author{
Lizbeth GONZÁLEZ VICTORIANO ${ }^{1}$, Norma GÜEMES VERA ${ }^{1 *}$ (D), Sergio SOTO SIMENTAL ${ }^{1}$, \\ Juan Pablo HERNÁNDEZ ${ }^{1}$, Aurora QUINTERO LIRA ${ }^{1}$, Javier PILONI MARTINI ${ }^{1}$
}

\begin{abstract}
The quality and physicochemical properties of dough and noodles made from blends of chayotextle flour and wheat semolina were investigated. The results showed that the inclusion of chayotextle flour increased both the hardness and adhesiveness of the dough, and there was a 10\% increase in cohesiveness and elasticity when using this particular flour. Regarding dough extensibility, no significant differences were found $(\mathrm{p}<0.05)$ in the control, while the proximal chemical analysis on dough showed that T1 (16.28\%) had a higher protein content compared to the control. These results indicate that the optimum mixture for the preparation of dough was obtained by using $10 \%$ chayotextle flour. It is concluded that incorporating appropriate amounts of this flour into wheat semolina during the production of dough maintains technological quality as well as texture and sensory perceptions.
\end{abstract}

Keywords: Sechium edule; noodles; texture.

Practical Application: the innovation of this work is el use of chayotextle flour in pastas products.

\section{Introduction}

Noodles is a very popular food in various countries around the world due to its low cost, easy production and sensory attributes. It also has a long shelf life and is considered a healthy food due to its low sodium content, produces a low glycemic response and provides good amounts of complex carbohydrates, proteins and vitamins (Tazrart et al., 2016). It is a fairly simple product that is obtained by mixing durum wheat semolina and water, followed by kneading, molding or extrusion. Conventional noodles is made using hard wheat semolina as the main ingredient, but there are studies that report different relationships between wheat semolina and other natural ingredients in the production of these types of products (Djeukeu et al., 2017). However, replacing semolina remains a challenge for the food industry, as the gluten in wheat semolina is the main structure-forming protein, and its absence results in technological and quality problems, so the addition of alternative ingredients markedly affects these properties (Larrosa et al., 2016; Lorusso et al., 2017). The technological process adopted in noodles production has a significant influence on the quality of the final product. One of the usual methodologies to produce gluten free noodles is to obtain pregelatinized starch through heating and cooling stages, thus forming a rigid network based on the retrograded starch (Larrosa et al., 2016).

Presently, some ingredients used in the production of noodles are rice and corn flours, pseudo cereal flours, vegetable proteins and starches of different origins such as potatoes or other tubers (Larrosa et al., 2013). However, the sticking properties of the starch in these types of ingredients play an important role in the quality of the product, as the starch provides the structure-forming properties. This behaviour is related to the macromolecules' tendency to re-associate and interact after gelatinization, resulting in organized structures that delay starch swelling and solubilization during cooking (Limroongreungrat \& Huang, 2007).

With this in mind, the use of new sources of starch such as those obtained from the tuberized root of the chayote (Sechium edule), better known as chayotextle, could be an alternative raw material, as it has a high production and high starch content $(60 \%$ dry basis) (Aila-Suárez et al., 2013). Therefore, the present study aims to evaluate the effect of adding chayotextle flour on the physico-chemical properties and in vitro digestibility of noodles as well as the quality of the final product.

\section{Materials and methods}

\subsection{Native flour, pre-gelatinized flour and mixtures of flours}

The raw flour of chayotextle and wheat semolina (Triticum durum) were purchased in the city of Tulancingo de Bravo, Hidalgo, Mexico. For the preparation of the chayotextle flour, the tubers were cut into slices of 2 to $3 \mathrm{~mm}$ and dehydrated in a drying oven (Luckie Stainless Furniture SA, CDMX, Mexico) at a controlled temperature of $40^{\circ} \mathrm{C}$ for $24 \mathrm{~h}$. They were then crushed and passed through a sieve ( $425 \mu \mathrm{m}$ mesh), to homogenize the particle size. For prepare chayotextle flour and wheat semolina pre-gelatinized; samples were hydrated with distilled water until to obtain 35 to $40 \%$ moisture content, immediately samples was packed in airtight bags and refrigerated for $12 \mathrm{~h}$. After this period, the pre-gelatinization was carried out using a single-screw extruder (Beutelspacher S.A. de C.V, México). The temperatures used for 
the chayotextle flour were: initial temperature (T0) $48-51^{\circ} \mathrm{C}$, intermediate temperature (Ti) $58-61{ }^{\circ} \mathrm{C}$ and final temperature (Tf) $56^{\circ} \mathrm{C}$ at $45 \mathrm{rpm}$. The wheat semolina was extruded at $\mathrm{T} 0$ $70^{\circ} \mathrm{C}$, Ti $83^{\circ} \mathrm{C}$ and $\operatorname{Tf} 80^{\circ} \mathrm{C}$ at $50 \mathrm{rpm}$. The extrudates obtained were dried at room temperature before proceeding to a second grinding and sieving to obtain the pre-gelatinized flour. After obtain these flours, it was to proceed to make mixtures as following proportions of wheat semolina and chayotextle flour of 90:10 (T1), 80:20 (T2) and 70:30 (T3), respectively.

\subsection{Flours, doughs and noodles analysis}

Flours were analysed for moisture content carried out by the method described in Association of Official Analytical Chemists (1990), using a drying oven (Wiseven Daihan WOF-105, Korea) at $100{ }^{\circ} \mathrm{C}$ until a constant weight was achieved $(24 \mathrm{~h})$.

\section{Available and resistant starch}

A small amount of sample of each treatment from both flours and noodles $(109 \mathrm{mg}$ ) was incubated with pancreatic $\alpha$-amylase and amyloglucosidase (AMG) in a water bath for $16 \mathrm{~h}$ at $37^{\circ} \mathrm{C}$. After this period, the reaction was completed by the addition of ethanol. The samples were then washed twice suspended in aqueous ethanol solution $(50 \% \mathrm{v} / \mathrm{v})$ followed by centrifugation. The remaining liquid was extracted by decantation and the resistant starch (AR) was dissolved in $2 \mathrm{M} \mathrm{KOH}$. The solution was neutralized with an acetate buffer and the starch was hydrolyzed quantitatively to glucose with AMG. Finally, D-glucose was measured with the glucose oxidase/peroxidase reagent (GOPOD), which is a measure of the AR content in the sample. On the other hand, the available starch (AS) was determined by bringing together the original supernatant and that from the washings, and by adjusting the volume to $100 \mathrm{~mL}$ to measure the content of $\mathrm{D}$-glucose with GOPOD (Martínez-Mora, 2015).

\section{Determination of gluten content}

Determining the gluten concentration was performed by following the 3810-AACC method (American Association of Cereal Chemists, 2000. Sufficient water was added to the sample $(20 \mathrm{~g})$ to form a firm dough, which was then left for $40 \mathrm{~min}$ water at room temperature. After this period the dough was washed under a stream of tap water with a Tyler sieve $(80 \mu \mathrm{m}$ mesh), until the starch and all the soluble matter were eliminated. The residue obtained was placed on an aluminium tray (weighed as wet gluten) and left in a drying oven at $100^{\circ} \mathrm{C}$ for $24 \mathrm{~h}$.

\section{Dough texture tests}

\section{Texture profile analysis}

A Texture Profile Analysis (TPA) on doughs was performed with a texture analyzer (CT3 Texture Analyzer-Brookfield, Germany). A $4.5 \mathrm{~kg}$ load cell was used with a $25 \mathrm{~g}$ sample placed in an acrylic cylinder and then compressed with a $3.50 \mathrm{~cm}$ diameter stainless steel probe for $15 \mathrm{~min}$. After this period two compression cycles were applied at a speed of
$10 \mathrm{~mm} / \mathrm{s}$ until 20\% deformation was reached, providing results related to hardness, cohesiveness, adhesiveness and springiness (Güemes-Vera et al., 2014).

\section{Dough extensibility}

For this test the dough was pressed in the "SMS / Kieffer" tool for $45 \mathrm{~min}$ to create and compact the strips. The samples were then inserted into the "Kieffer Dough and Gluten Extensibility Rig" sample plate, and the pretest and speed tests were set at 0.5 and $2 \mathrm{~mm} / \mathrm{s}$, respectively, applying a distance of $50.0 \mathrm{~mm}$. The output values were provided as extensibility in $\mathrm{mm}$ (distance at rupture) (Shiau et al., 2015).

\section{Preparation of noodles}

For the preparation of the noodles, wheat semolina and chayotextle flour (previously pre-gelatinized and crushed) were mixed in ratios of $(90: 10) \mathrm{T} 1,(80: 20) \mathrm{T} 2$, and (70:30) T3, respectively. The noodles were then prepared according to the method as described by Jeong et al. (2017) with some modifications. Firstly, $200 \mathrm{~g}$ of each formulation were mixed with water to produce homogenous dough which was allowed to stand for $15 \mathrm{~min}$. Then, small portions of dough were passed through rolling mill rolls (BE-8200, Bethel, Seoul, Korea), and the dough sheets were cut in the form of noodles $(100 \mathrm{~mm}$ long and $5 \mathrm{~mm}$ wide). The noodles obtained were then dried at room temperature and packed in an airtight container for further analysis.

\section{Proximal chemical analysis of the noodles}

The composition of the noodles was evaluated by a proximal chemical analysis, using the official methods recommended by the Association of Official Analytical Chemists (1990). Protein quantification was performed using the Kjendahl method AOAC 988.05, crude fiber with the method AOAC 962.09, ash and fat using the methods AOAC 942.05 - 920.30 , respectively, and the determination of carbohydrates was done by difference. All trials were carried out in triplicate.

\section{Tensile property measurement of the noodles}

To carry out this test, the noodles were cooked for $5 \mathrm{~min}$. A strand of cooked noodle was then placed in the "Kieffer Dough and Gluten Extensibility Rig", and the middle of the noodle strands was pulled upwards by the hook at a crosshead speed of $2 \mathrm{~mm} / \mathrm{s}$ until they were fractured. Extensibility was measured from the force-distance curves obtained (Jeong et al., 2017).

\section{Color characteristics of the noodles}

The color of the uncooked noodles was measured using a colorimeter (MicrOptix S560 i-LAB, USA). The color readings were expressed using the CIELAB system $\left(\mathrm{L}^{*}, \mathrm{a}^{*}\right.$ and $\left.\mathrm{b}^{*}\right)$. The of $\mathrm{L}^{\star}$ values measure black to white $(0-100)$, the $\mathrm{a}^{\star}$ values measure redness when positive and $\mathrm{b}^{*}$ values measure the yellowness when positive (Chauhan et al., 2017). 


\section{Sensory evaluation of noodles}

As a final test, a sensory analysis was carried out according to the technique described by Anzaldua (1994), with a preference test to compare the acceptability of noodles with 10 and $20 \%$ chayotextle flour. A total of 30 consumer-type panellists took part in the sensory evaluation. All samples were cooked in boiling water for $10 \mathrm{~min}$ and the attributes evaluated were color, firmness, taste and general acceptability.

\section{Statistical analysis}

A completely randomized design was applied in this investigation, and the data was analyzed by means of an analysis of variance (ANOVA). The results were subjected to a Dunnett test to determine the significant differences $(\mathrm{P}<0.05)$ of the different mixtures in the control. All the analysis was carried out using the NCSS10 software package (Data Analysis, USA).

\section{Results and discussion}

\subsection{Physical-chemical characterization of native and pre-gelatinized flours}

\section{Moisture content}

Moisture content is used as an indicator of food quality, so it is necessary to determine it in order to know the impact on the sensory and physical properties of a product (Hathorn et al., 2008). In Table 1 it can be observed that, for native flours, the chayotextle flour (CF) had a moisture content of $8.89 \pm 0.34$ and showed significant differences $(\mathrm{p}<0.05)$ when compared to the control (10.91 \pm 0.26$)$. Similar results were reported by Kaur et al. (2019), where moisture content decreased (6.40 to $2.20 \%$ ) as the amount of flaxseed meal increased from 10 to $30 \%$. It is important to mention that a low moisture content indicates better stability during storage to maintain the quality of the starch (Falade et al., 2014).

Regarding the moisture content in pre-gelatinized flours (Table 2$)$ there were also significant differences $(\mathrm{p}<0.05)$ between the treatments in the control (11.09\%). It should be noted that these flours presented higher moisture content compared with native flours. This was probably due to the crystalline parts altering to amorphous during pre-gelatinization, which made them more likely to absorb more moisture. Homogenously amorphous starch is tightly packed with a reduced capacity to absorb water, and thus has a as with low moisture content (Karrila \& Karrila, 2017). However, the final moisture content is still acceptable for this type of product as reported in a study conducted by Odeku et al. (2008) where pre-gelatinized starches had water content of $10-12 \%(\mathrm{w} / \mathrm{w})$. The study mentions that the maximum water content prescribed for safe storage by most starch producing countries is $13 \% \mathrm{w} / \mathrm{w}$. Higher levels of water have been known to affect the flow and mechanical properties of starches and can lead to microbial spoilage and subsequent deterioration in starch quality.

Table 1. Texture, digestibility and color of doughs prepared using chayotextle native flour.

\begin{tabular}{|c|c|c|c|c|c|}
\hline & Control & $\mathrm{T} 1$ & $\mathrm{~T} 2$ & T3 & $\mathrm{HCH}$ \\
\hline Moisture (\%) & $10.91 \pm 0.26$ & $10.86 \pm 0.12$ & $10.62 \pm 0.44$ & $10.29 \pm 0.47$ & $8.89 \pm 0.34^{*}$ \\
\hline Aw & $0.568 \pm 0.003$ & $0.551 \pm 0.001^{*}$ & $0.551 \pm 0.002^{*}$ & $0.536 \pm 0.002^{*}$ & $0.491 \pm 0.004^{\star}$ \\
\hline Available Starch (\%) & $28.75 \pm 1.01$ & $4.48 \pm 1.84^{*}$ & $18.10 \pm 0.11^{\star}$ & $9.57 \pm 1.31^{\star}$ & $0.13 \pm 0.06^{*}$ \\
\hline Resistant starch (\%) & $0.44 \pm 0.02$ & $9.32 \pm 0.36^{*}$ & $12.69 \pm 0.55^{*}$ & $23.64 \pm 0.30^{*}$ & $46.33 \pm 1.83^{*}$ \\
\hline Gluten content $(\%)$ & $10.67 \pm 0.01$ & $10.34 \pm 0.17$ & $10.15 \pm 0.03$ & $8.52 \pm 0.05^{*}$ & ND \\
\hline Firmness (kg) & $0.91 \pm 0.07$ & $1.17 \pm 0.05$ & $1.38 \pm 0.08^{*}$ & $1.52 \pm 0.09^{*}$ & $4.42 \pm 0.21^{*}$ \\
\hline Adhesiveness (g.s) & $7.95 \pm 0.23$ & $16.65 \pm 1.62$ & $21.49 \pm 1.31$ & $25.04 \pm 1.93$ & $63.41 \pm 3.72^{\star}$ \\
\hline Cohesiveness (-) & $0.58 \pm 0.03$ & $0.64 \pm 0.01$ & $0.65 \pm 0.04$ & $0.64 \pm 0.05$ & $0.28 \pm 0.07^{*}$ \\
\hline Springiness (-) & $0.88 \pm 0.01$ & $0.96 \pm 0.001$ & $0.96 \pm 0.01$ & $0.96 \pm 0.01$ & $0.62 \pm 0.04^{*}$ \\
\hline Extensibility (mm) & $46.19 \pm 3.58$ & $44.30 \pm 2.58$ & $44.06 \pm 1.60$ & $39.37 \pm 1.08^{*}$ & ND \\
\hline
\end{tabular}

${ }^{\star}$ Symbol indicate significant differences between control to others treatments (P< 0.05). ND: Non-determined; Control: wheat semolina (ST); T1: (90:10; ST:HCH); T2: (80/20; ST:HCH); T3: (70/30; ST:HCH); HCH: chayotextle flour.

Table 2. Moisture, activity of water and texture of doughs prepared using chayotextle pregelatinized flour.

\begin{tabular}{lccccc}
\hline & Control & T1 & T2 & T3 & HCH \\
\hline Moisture (\%) & $11.09 \pm 0.99$ & $11.69 \pm 0.19$ & $11.73 \pm 0.54$ & $11.86 \pm 0.45$ & $12.53 \pm 0.19^{*}$ \\
$\mathrm{a}_{\mathrm{w}}(-)$ & $0.574 \pm 0.003$ & $0.564 \pm 0.005^{*}$ & $0.555 \pm 0.001^{*}$ & $0.537 \pm 0.002^{*}$ & $0.595 \pm 0.001^{\star}$ \\
Firmness (kg) & $3.44 \pm 0.31$ & $3.84 \pm 0.09$ & $3.94 \pm 0.07$ & $4.46 \pm 0.07^{\star}$ & $4.67 \pm 0.01^{\star}$ \\
Adhesiveness (g.s) & $33.92 \pm 2.14$ & $69.77 \pm 2.76^{*}$ & $64.91 \pm 1.91^{*}$ & $51.60 \pm 0.55^{*}$ & $69.25 \pm 2.46^{*}$ \\
Cohesiveness (-) & $0.34 \pm 0.21$ & $0.38 \pm 0.09$ & $0.35 \pm 0.02$ & $0.28 \pm 0.04$ & $0.29 \pm 0.05$ \\
Springiness (-) & $0.68 \pm 0.44$ & $0.65 \pm 0.25$ & $0.57 \pm 0.06$ & $0.53 \pm 0.04$ & $0.05 \pm 0.03^{*}$ \\
Extensibility (mm) & $11.96 \pm 1.78$ & $11.83 \pm 0.96$ & $11.52 \pm 0.97$ & $11.43 \pm 2.22$ & $\mathrm{ND}$ \\
\hline
\end{tabular}

${ }^{*}$ Symbol indicate significant differences between control to others treatments (P < 0.05). ND: Non-determined; Control: wheat semolina (ST); T1: (90:10; ST:HCH); T2: (80/20; ST:HCH); T3: (70/30; ST:HCH); HCH: chayotextle flour. 


\subsection{Water activity}

The $\mathrm{a}_{\mathrm{w}}$ interval is measured within the range of 0 to 1.0 , and flours generally have a low $\mathrm{a}_{\mathrm{w}}$ level. As such, they can be classified as intermediate moisture foods, presenting an $\mathrm{a}_{\mathrm{w}}$ ranging from 0.60 to 0.90 , which makes storage possible at room temperature with a longer shelf life than fresh foods (Tortoe et al., 2009; Rodríguez-Miranda et al., 2011). Table 1 shows the results obtained for this parameter. In native flours, significant differences were found between the treatments $(\mathrm{p}<0.05)$ in the control $(0.568 \pm 0.003)$, with CF presenting the lowest $\mathrm{a}_{\mathrm{w}}$ value $(0.491 \pm 0.004)$. In pre-gelatinized flours, the CF exhibited the highest value $(0.595 \pm 0.001)$ in the control $(0.574 \pm 0.003)$. The $\mathrm{a}_{\mathrm{w}}$ presented in pre-gelatinized flours was higher than with native flours, which is in accordance with studies conducted by Tadapaneni et al. (2017). They report that the $\mathrm{a}_{\mathrm{w}}$ of food powders with hydrophilic macromolecules of a specific moisture content increases with the temperature, caused by the temperature induced breakage of molecular bonds between water molecules and $\mathrm{OH}$ groups in foods, indicating that the degree of increase in the $\mathrm{a}_{\mathrm{w}}$ is dependent on the amount of hydrophilic groups (HG) present in the food product. The authors also mention that when food samples are thermally treated in a closed system, the increase in $a_{w}$ could be attributed to the alleviation of the molecular bonds between food biopolymers and water alleviate which would release free water molecules.

\subsection{Digestibility and hydrolysis of starch in native flours}

The digestion of starch has been the subject of extensive research, mostly involving in vitro measurement of the susceptibility of starches to attack by different enzymes, rather than measuring actual digestibility in vivo (Copeland et al., 2009). In this study, a high total starch content was found in CF (46.45 $\pm 1.78 \%)$, compared to the control $(29.19 \pm 0.99 \%)$. However, a significant proportion of this is not available for hydrolysis by digestive enzymes, since in determining the content of available starch (AS) in CF, the proportion found was $0.13 \%$ (Table 1). Eleazu et al. (2018) mention that the low digestibility in tubular starches (TS) is due to their high content of resistant starch. However, there are other factors that influence the enzymatic bioavailability of starch and the speed of digestion, such as the particle size, surface area of the granules and the ratio of amylopectin, as these factors affect the level of hydrolysis of a-amylase (Xing-Li et al., 2016). Besides the amylose content, the size and morphology of the granules, the degree of crystallinity or mechanical damage has a strong impact on enzymatic resistance (Zhao et al., 2018).

Regarding the resistant starch (RS) content, CF also presented the highest value $(46.33 \pm 1.83 \%)$ in the control $(0.44 \pm 0.02 \%)$, as shown in Table 1 . This can be attributed to the fact that native potato starch granules are less accessible to amylolitic enzymes due to their large, compact and homogeneous granules and smooth surfaces (Zhao et al., 2018). There are several factors that influence digestibility, among them the proportion of amylose-amylopectin, the minor components of starch such as protein and fat which form complexes with amylose and affect enzyme susceptibility (Horstmann et al., 2017). In a study conducted by Lovera et al. (2017), higher RS content in yam and potato starches was recorded, which indicates that resistance to enzymatic digestion is also associated with starches whose granular crystal organization corresponds to the type B X-ray diffraction pattern.

\subsection{Gluten content}

Gluten-forming proteins play key roles in the extensibility and elasticity of dough, and gluten quality is considered one of the most important quality parameters of wheat flour (Guo et al., 2018). Table 1 shows the results of the gluten content in the different treatments, and one can observe that $\mathrm{T} 3$ $(1.70 \pm 0.05)$ presents a significant difference $(\mathrm{p}<0.05)$ compared to the control $(2.13 \pm 0.01)$, indicating that gluten content decreases with increasing CF concentration. Some authors have reported that the total or partial replacement of wheat flour dilutes the gluten network. One study reported that replacing wheat flour with purple yam flour (Dioscorea alata) resulted in a decrease in gluten content (Li et al., 2012). This effect may be due to a number of physical and chemical interactions that interfere directly in the dough's stability, because it depends on the number of links between protein molecules present in the gluten and the strength of these connections (Boita et al., 2016).

\subsection{Texture profile analysis}

The data reported in Table 1 show the results obtained from a Texture Profile Analysis (TPA) performed on the doughs. For hardness, significant differences were found between the control dough treatments $(0.91 \pm 0.07 \mathrm{~kg})$, except for the treatment with $10 \%$ of CF $(1.17 \pm 0.05 \mathrm{~kg})$ and increases in this parameter were linked to the concentration of CF. This can be attributed to the interactions between the components of potato and wheat flours and/or the greater water absorption in the potato-wheat system (Pu et al., 2017). Another factor could be the fiber present in potato flour. Shiau et al. (2015) state that potato fiber contains a high level of insoluble fibers, and when incorporated into the dough system there is competition for water absorption between fiber and wheat flour components. This interferes with the formation of the gluten network and leads to an increase in hardness.

Regarding adhesiveness, only CF showed significant differences $(\mathrm{p}<0.05)$ compared with the control (Table 1$)$, with values of $63.41 \pm 3.72$ and $7.95 \pm 0.23$ g.s, respectively. It should be noted that there was an increase depending on the concentration of CF. Marpalle et al. (2014) observed an increase in dough adhesiveness by increasing the concentration of flaxseed meal and indicated that high water absorption leads to a decrease in the water binding capacity with gluten, therefore increasing adhesiveness. On the other hand, the degree of adhesiveness depends on the quantity and quality of the starch and its state of gelatinization (Mirhosseini et al., 2015). Regarding cohesiveness, there were also significant differences $(\mathrm{p}<0.05)$ between $\mathrm{CF}$ $(0.28 \pm 0.07)$ compared to the control $(0.58 \pm 0.03)$, and it was observed that adding CF increased the cohesiveness of the dough. Ben Jeddou et al. (2017) analyzed dough with up to $10 \%$ of potato peel and noticed a great improvement in the texture properties, showing an increase in the cohesion, adhesion and hardness of the dough. Similarly, a study conducted on gluten-free breads found an increase in the cohesiveness of the crumbs, and bread 
added with cassava starch had greater cohesiveness than those that contained only corn starch (Onyango et al., 2011).

When incorporating CF there was an increase in elasticity depending on the amount incorporated with values of $0.88 \pm 0.01$ for the control, and up to $0.96 \pm 0.01$ for T3. An important factor in increasing elasticity is the hydration capacity of flour, which depends on the particle size, the amount of damaged starch as a result of grinding, protein content, as well as the changes in water-binding which modifies the structure of the dough brought about by the hydration of starch (Witczak et al., 2012).

Table 1 also presents the results of TPA for pre-gelatinized flours. In terms of hardness T3 $(4.46 \pm 0.07)$ and CF $(4.67 \pm 0.01)$ showed significant differences $(\mathrm{p}<0.05)$ compared to the control $(3.44 \pm 0.31)$, while for adhesiveness all the treatments showed significant differences compared to the control (33.92 \pm 2.14$)$. It is important to mention that the values of both parameters increased when compared with the native flour treatments. This is due to the fact that during pre-gelatinization the molecular arrangement of the starch collapses and irreversible changes to its properties take place, such as a loss of crystallinity, absorption of water and swelling of the granules. Consequently, this promotes the interaction of the polymer chains by interrupting the crystalline structure and disassociating the double helical structure in the amorphous region, followed by rearrangement of the disrupted crystals (Zavareze \& Dias, 2011). Another factor could be the quantity of damaged starch, as during the pre-gelatinization process, there is an increase in the content of this starch, probably due to the damage produced by shear stress and the temperature on the starch granules during extrusion (Martínez et al., 2014).

On the other hand, no significant differences were found with cohesiveness $(\mathrm{p}<0.05)$ between the treatments compared to the control dough, with T1 presenting a high value $(0.38 \pm 0.09)$. Regarding elasticity, only CF $(0.05 \pm 0.03)$ showed significant difference compared to the control $(0.68 \pm 0.44)$. It is important to note that a decrease in these parameters is observed when compared with the results obtained in native flours, which is attributed to the high temperatures that were applied during the pre-gelatinization process. This is in line with a study by Martínez et al. (2013), which states that dough's stability tends to decrease with increasing extrusion intensity, as stability depends on the characteristics of the protein network. This reduction in stability may therefore be related to the degradation of the gluten matrix occurring during the extrusion process, due to the increase in temperature, as high-temperature treatments will modify the characteristics of the components of the gluten matrix.

\subsection{Dough extensibility}

Table 1 shows the results of extensibility of native flours. In native flours, there was a decrease in extensibility when increasing the amount of CF, but only T3 $(39.37 \pm 1.08 \mathrm{~mm})$ showed a significant difference $(\mathrm{p}<0.05)$ compared to the control $(46.19 \pm 3.58 \mathrm{~mm})$. This decrease causes a negative effect on the formation of the gluten network resulting in a harder dough (Struck et al., 2018). Similar results were found by Boita et al. (2016), where increasing the levels of bran from 25\% to $100 \%$ gradually decreased both the resistance to extension and the extensibility of the dough from 30.00 to $19.67 \mathrm{~mm}$, respectively. The authors explain that the effects in the reduction of the extensibility properties of the dough are related to the changes in the gluten network caused by the incorporation of the bran: high levels of bran incorporated into the flour caused a greater dilution of the matrix, thus weakening its extensible characteristics.

\subsection{Dough extensibility chayotextle pregelatinized flour}

The Table 2 showed that in pre-gelatinized flours the same tendency of decreasing extensibility was found when increasing the concentration of CF when compared to the control (11.96 \pm 1.78$)$. It is important to mention that the addition of extruded flours drastically decreases the extensibility of the dough in all cases, compared with the extensibility of doughs made with native flours. These variations in the characteristics of extensibility can be related to two factors: the degradation of the gluten matrix and the modification of starch. These are consequences of the extrusion treatment, because the degradation of the gluten matrix increases with the intensity of the treatment. On the other hand, the modification of the starch during the extrusion process leads to an increase in the consistency in the dough due to an increase in the amount of damaged starch and its greater water absorption capacity (Martínez et al., 2013).

\subsection{Evaluation of the quality of noodles}

\section{Proximal chemical analysis}

The proximal chemical composition of CF, the control noodles and the noodles with $10 \%$ CF (T1) were determined (Table 3). The obtained results showed that CF presented a fiber content of $3.95 \%$ and ash content of $6.21 \%$, which can be attributed to the significant amount of minerals present in roots and tubers (Njintang et al., 2008). The moisture content was $7.70 \%$, and Yadav et al. (2014) found similar results in different flours where the moisture content varied from 6.0 to $8.5 \%$. Carbohydrates (72.95\%) are the main components of the flours, with starch the most important natural element of this group. This carbohydrate content differs with that reported by Jiménez-Hernández et al. (2007) for chayotextle starch, which can be attributed to the maturation of the tuber or to the differences in content of other constituents (Yadav et al. 2014).

Table 3. Proximal chemical analysis of noodles using chayotextle flour.

\begin{tabular}{lrcr}
\hline & \multirow{2}{*}{ Control } & \multicolumn{2}{c}{ Treatments } \\
\cline { 3 - 4 } & & HCH & T1 \\
\hline Protein (\%) & $15.98 \pm 0.08$ & $9.19 \pm 0.03$ & $16.21 \pm 0.2$ \\
Moisture (\%) & $8.95 \pm 0.02$ & $7.70 \pm 0.02$ & $7.48 \pm 0.4$ \\
Crude Fat (\%) & $0.43 \pm 0.04$ & $0 \pm 0$ & $0.37 \pm 0.15$ \\
Crude fiber (\%) & $0.55 \pm 0.01$ & $3.95 \pm 0.1$ & $0.46 \pm 0.01$ \\
Ash (\%) & $0.61 \pm 0.01$ & $6.21 \pm 0.03$ & $1.07 \pm 0.04$ \\
Carbohydrates (\%) & $73.48 \pm 0.19$ & $72.95 \pm 0.01$ & $74.41 \pm 0.01$ \\
\hline
\end{tabular}

HCH: chayotextle flour; T1: (90:10; ST:HCH). 
Regarding the chemical composition of noodles, $\mathrm{T} 1$ showed a protein, ash and carbohydrate content of $16.21,1.07$ and $74.41 \%$, respectively, which was higher than the control noodles (15.98, 0.61 and $73.48 \%$, respectively). Similar results were reported by Djeukeu et al. (2017), where an increase in the ash content when incorporating yam flour into the noodles was observed, stating that tubers are a rich source of minerals. For protein content, the control presented a higher protein content compared to T1, which could be attributed to the fact that cereals generally have a higher content of these compounds (Rodríguez-Miranda et al., 2011). Regarding moisture content, fat and fiber, the control noodles presented values of $8.95,0.43$ and $0.55 \%$, respectively, while for M1 they were $7.48,0.37$ and $0.46 \%$, respectively. This could be due to the fact that, when replacing ST, the content of these components also decreases, because CF has a lower moisture $(7.70 \%)$ and fat $(0 \%)$ content.

\subsection{Color of noodles}

The color of fresh noodles is a very important quality attribute that greatly influences consumer acceptance, and it is the first property that consumers can evaluate when selecting a product in the market (Armellini et al., 2018). Table 4 presents the noodles color data, and it can be observed that the $\mathrm{L}^{*}$ values decreased when incorporating CF, with the control noodles having the highest $\mathrm{L}^{*}$ value $(63.13 \pm 2.47)$. There was also a significant increase in the red color index $\left(\mathrm{a}^{\star}\right)$, and a decrease in yellowness $\left(b^{\star}\right)$, showing significant differences $(p<0.05)$ between the treatments compared to the control. Similar reports were found in noodles with added amaranth flour, which showed a significant decrease in the $b^{*}$ value after drying and an increase in the $a^{*}$ value. The authors point out that both the decrease in brightness in the noodles and the increase in the red color index are related to the development of the Maillard reactions that take place during drying, especially when humidity ranges between 15 and 18\% (Islas-Rubio et al., 2014).

Similar behavior was observed in cakes enriched with potato peel powder, where higher $\mathrm{L}^{*}$ values were observed in the control compared with the samples supplemented with potato peel powder. When the level of this powder increased, the values of $\mathrm{L}^{\star}$ decreased from 106.13 for the control to 72.96 in noodles with up to $10 \%$ potato peel powder. As a result, $b^{*}$ values decreased and $a^{*}$ values increased based of the percentage of incorporation. This effect can result from a more pronounced non-enzymatic browning when wheat flour is replaced by fiber with different sugar compositions (Ben Jeddou et al., 2017). There are other factors that influence such browning, such as $\mathrm{a}_{\mathrm{w}}, \mathrm{pH}$, temperature, sugars, as well as the type and proportion of amino compounds (Sharma \& Gujral, 2014).

\subsection{Digestibility and hydrolysis of starch}

The starch accessible to the enzymatic action in noodles was used as an indicator of the changes that the starch underwent through the different technological stages to which the CF and treatments without extrusion (TWE) were subjected during the pre-gelatinization, the elaboration process of noodles and the cooking treatment. In Table 4 , it can be observed that there are no significant differences $(\mathrm{p}<0.05)$ for AS between treatments compared to the control noodles (48.64\%). However, with RS content, significant differences were found compared to the control $(2.88 \%)$.

Regardless of this trend in the treatments, there was an increase in both AS and TS in the noodles compared to the raw material used (native flours) which can be attributed to the extrusion process to which the flours were subjected before the processing of noodles. Extrusion leads to fragmentation of amylose and this amylose fragmentation makes starch more vulnerable to attack by enzymes, thereby yielding greater oligosaccharide production, such as maltose (Rafiq et al., 2017). Additionally, as the gelatinisation goes on, the progressive disorganisation of starch granules allows an increase in accessibility to the enzymatic action. This process also provokes a reorganization of starch molecules that modifies the physicochemical properties of starches. The principal changes are decrease in the swelling power and solubility increase in enzyme susceptibility and decrease in peak viscosity and retrogradation tendency (Mariotti et al., 2011; Osundahunsi et al., 2011). In general, the susceptibility to enzymatic hydrolysis increases and the amount of RS decreases as extrusion severity increases (Martínez et al., 2014).

\subsection{Noodles extensibility}

Extensibility is the measurement of the distance at which the noodles is fractured during extension (Chauhan et al., 2017). In the table 3 showed this test, a decrease in extensibility was observed when increasing the concentration of CF, with M3 having the lowest extensibility value $(2.76 \pm 0.48 \mathrm{~mm})$ compared to the control $(3.34 \pm 0.54 \mathrm{~mm})$. It is necessary to mention that the extensibility values of the noodles were lower compared to

Table 4. Color, extensibility and starches of noodles prepared using chayotextle flour.

\begin{tabular}{|c|c|c|c|c|c|}
\hline \pm & Control & $\mathrm{T} 1$ & $\mathrm{~T} 2$ & $\mathrm{~T} 3$ & \pm \\
\hline $\mathrm{L}^{*}$ & $63.13 \pm 2.47$ & $53.38 \pm 1.57^{*}$ & $43.69 \pm 0.99^{*}$ & $43.40 \pm 0.74^{\star}$ & ND \\
\hline$a^{*}$ & $12.69 \pm 0.47$ & $14.53 \pm 0.87^{\star}$ & $18.65 \pm 1.17^{\star}$ & $11.43 \pm 0.62$ & ND \\
\hline Extensibility (mm) & $3.34 \pm 0.54$ & $3.10 \pm 0.73$ & $2.92 \pm 0.39$ & $2.76 \pm 0.48$ & ND \\
\hline Available Starch (\%) & $48.64 \pm 0.17$ & $47.33 \pm 0.41$ & $48.87 \pm 1.81$ & $47.95 \pm 0.54$ & ND \\
\hline
\end{tabular}

${ }^{\star}$ Symbol indicate significant differences between control to others treatments (P< 0.05); ND: Non-determined; Control: wheat semolina (ST); T1: (90:10; ST:HCH); T2: (80/20; ST:HCH); T3: (70/30; ST:HCH); HCH: chayotextle flour. 
the extensibility of native flours. This could be attributed to the fact that before the elaboration of the product, the raw material was subjected to an extrusion process to produce a good amount of retrograded starch. This process weakens the protein matrix and, as a result, the product does not have a continuous and compact protein network, which influences the microstructural properties of the noodles (Zardetto \& Dalla Rosa, 2009). In a study conducted by Jeong et al. (2017) it was reported that noodles substituted with 5 and $10 \%$ rice flour had less extensibility (5.04 and $3.73 \mathrm{~mm}$, respectively) compared to noodles made with wheat flour $(17.15 \mathrm{~m})$. Such behavior is attributed to the increasing amounts of gluten-free proteins, since a discontinuous gluten matrix leads to changes in the resistance and extensibility of the dough, weakening its overall structure, which in turn directly influences the textural properties of the final product (Islas-Rubio et al., 2014; Xing-Li et al., 2016).

\subsection{Sensory analysis}

The sensory evaluation considers the subjective estimation of the consumers and allows the general performance of the quality of a product to be evaluated. Also, the results obtained are useful to further establish the relationship between the raw material and the final product (Pu et al., 2017). In this study, sensory characteristics such as appearance, color, texture and total acceptability of noodles with 10 and 20\% CF (T1 and T2, respectively) were evaluated, and the results obtained indicated a $100 \%$ acceptability of the new product, but $53.33 \%$ of the judges expressed a preference for the T1 noodles. It should be noted that the difference in percentage was minimal, but the panellists mentioned that $\mathrm{T} 2$ presented better firmness compared to $\mathrm{T} 1$, but it did not have a very desirable color. In a study conducted by Xing-Li et al. (2016) it was reported that there was a significant change in the color of the bread when incorporating potato flour, producing a darker color. The authors noticed that breads added with 10 and $20 \%$ of potato flour received a higher score of general acceptability. On the other hand, Li et al. (2012) reported that noodles made of wheat flour mixed with up to $15 \%$ purple yam flour (Dioscorea alata L.), showed greater firmness and stiffness than the control sample, and noodles that contained between 5 and $15 \%$ of this flour received the same acceptability scores as the control.

\section{Conclusions}

It is important to know how the addition of unconventional ingredients affects the physical and mechanical characteristics of dough, because these attributes are important in predicting the behavior of doughs during manufacturing and the quality of the finished product. From the results obtained in this study, it is possible to conclude that the use of pregelatinized chayotextle flour can be an alternative in the elaboration of gluten free or low gluten content products. Using this flour provides products with good technological and commercial characteristics, as with products made only with wheat flour, the gluten protein is responsible for forming a network of proteins which provides the cooking quality and good texture properties. It was also observed that some starch properties such as retrogradation have an important effect on the physicochemical characteristics, as well as on the final texture of the product.

\section{References}

Aila-Suárez, S., Palma-Rodriguez, H. M., Rodríguez-Hernández, A. I., Hernández-Uribe, J. P., Bello-Pérez, L. A., \& Vargas-Torres, A. (2013). Characterization of films made with chayote tuber and potato starches blending with cellulose nanoparticles. Carbohydrate Polymers, 98(1), 102-107. http://dx.doi.org/10.1016/j.carbpol.2013.05.022. PMid:23987322.

American Association of Cereal Chemists - AACC. (2000). Approved methods of the American Association of Cereal Chemists. St. Paul: AACC. Retrieved from: http://methods.aaccnet.org/default.aspx

Anzaldua, M. A. (1994). La evaluación sensorial de los alimentos en la teoría y la práctica. Zaragoza: Acribia.

Armellini, R., Peinado, I., Pittia, P., Scampicchio, M., Heredia, A., \& Andres, A. (2018). Effect of saffron (Crocus sativus L.) enrichment on antioxidant and sensorial properties of wheat flour pasta. Food Chemistry, 254, 55-63. http://dx.doi.org/10.1016/j.foodchem.2018.01.174. PMid:29548471.

Association of Official Analytical Chemists - AOAC. (1990). Official methods of analysis of Association of Official Analytical Chemists (15th ed.). Washington: AOAC.

Ben Jeddou, K., Bouaziz, F., Zouari-Ellouzi, S., Chaari, F., Ellouz-Chaabouni, S., Ellouz-Ghorbel, R., \& Nouri-Ellouz, O. (2017). Improvement of texture and sensory properties of cakes by addition of potato peel powder with high level of dietary fiber and protein. Food Chemistry, 217, 668-677. http://dx.doi.org/10.1016/j.foodchem.2016.08.081. PMid:27664685.

Boita, E. R. F., Oro, T., Bressiani, J., Santetti, G. S., Bertolin, T. E., \& Gutkoski, L. C. (2016). Rheological properties of wheat flour dough and pan bread with wheat bran. Journal of Cereal Science, 71, 177182. http://dx.doi.org/10.1016/j.jcs.2016.08.015.

Chauhan, A., Saxena, D. C., \& Singh, S. (2017). Effect of hydrocolloids on microstructure, texture and quality characteristics of gluten-free pasta. Journal of Food Measurement and Characterization, 11(3), 1188-1195. http://dx.doi.org/10.1007/s11694-017-9495-4.

Copeland, L., Blazek, J., Salman, H., \& Tang, C. M. (2009). Form and functionality of starch. Food Hydrocolloids, 23(6), 1527-1534. http:// dx.doi.org/10.1016/j.foodhyd.2008.09.016.

Djeukeu, W. A., Gouado, I., Leng, M. S., Vijaykrishnaraj, M., \& Prabhasankar, P. (2017). Effect of dried yam flour (Dioscorea schimperiana) on cooking quality, digestibility profile and antioxidant potential of wheat based pasta. Journal of Food Measurement and Characterization, 11(3), 1421-1429. http://dx.doi.org/10.1007/ s11694-017-9521-6.

Eleazu, C., Sampson, A., Saidu, S., Eleazu, K., \& Egedigwe-Ekeleme, C. (2018). Starch digestibility, polyphenol contents and in vitro alpha amylase inhibitory properties of two varieties of cocoyam (Colocassia esculenta and Xanthosoma mafafa) as affected by cooking. Journal of Food Measurement and Characterization, 12(2), 1047-1053. http:// dx.doi.org/10.1007/s11694-018-9720-9.

Falade, K. O., Semon, M., Fadairo, O. S., Oladunjoye, A. O., \& Orou, K. K. (2014). Functional and physico-chemical properties of flours and starches of African rice cultivars. Food Hydrocolloids, 39, 41-50. http://dx.doi.org/10.1016/j.foodhyd.2013.11.002.

Güemes-Vera, N., González-Victoriano, L., Soto-Simental, S., HernándezChávez, J. F., \& Reyes-Santamaria, M. I. (2014). Mechanical properties of cottage cheese-fortified wheat dough and loaf bread. Journal of Food Science and Technology, 51(10), 2797-2802. http://dx.doi. org/10.1007/s13197-012-0746-4. PMid:25328228. 
Guo, X., Sun, X., Zhang, Y., Wang, R., \& Yan, X. (2018). Interactions between soy protein hydrolyzates and wheat proteins in noodle making dough. Food Chemistry, 245, 500-507. http://dx.doi.org/10.1016/j. foodchem.2017.10.126. PMid:29287401.

Hathorn, C. S., Biswas, M. A., Gichuhi, P. N., \& Bovell-Benjamin, A. C. (2008). Comparison of chemical, physical, micro-structural, and microbial properties of breads supplemented with sweet potato flour and high-gluten dough enhancers. Lebensmittel-Wissenschaft + Technologie, 41(5), 803-815. http://dx.doi.org/10.1016/j.lwt.2007.06.020.

Horstmann, S. W., Lynch, K. M., \& Arendt, E. K. (2017). Starch characteristics linked to gluten-free products. Foods, 6(4), 29-50. http://dx.doi.org/10.3390/foods6040029. PMid:28383504.

Islas-Rubio, A. R., Calderón de la Barca, A. M., Cabrera-Chávez, F., CotaGastélum, A. G., \& Beta, T. (2014). Effect of semolina replacement with a raw: popped amaranth flour blend on cooking quality and texture of pasta. Lebensmittel-Wissenschaft + Technologie, 57(1), 217-222. http://dx.doi.org/10.1016/j.lwt.2014.01.014.

Jeong, S., Kim, H. W., \& Lee, S. (2017). Rheological and secondary structural characterization of rice flour-zein composites for noodles slit from gluten-free sheeted dough. Food Chemistry, 221, 1539-1545. http://dx.doi.org/10.1016/j.foodchem.2016.10.139. PMid:27979127.

Jiménez-Hernández, J., Salazar-Montoya, J. A., \& Ramos-Ramírez, E. G. (2007). Physical, chemical and microscopic characterization of a new starch from chayote (Sechium edule) tuber and its comparison with potato and maize starches. Carbohydrate Polymers, 68(4), 679686. http://dx.doi.org/10.1016/j.carbpol.2006.07.035.

Karrila, T., \& Karrila, S. (2017). A switch point model for high-resolution moisture absorption isotherms of raw and pregelatinized starches. Journal of Food Measurement and Characterization, 11(4), 15921601. http://dx.doi.org/10.1007/s11694-017-9539-9.

Kaur, P., Sharma, P., Kumar, V., Panghal, A., Kaur, J., \& Gat, Y. (2019). Effect of addition of flaxseed flour on phytochemical, physicochemical, nutritional, and textural properties of cookies. Journal of the Saudi Society of Agricultural Sciences, 18(4), 372-377. http://dx.doi. org/10.1016/j.jssas.2017.12.004.

Larrosa, V., Lorenzo, G., Zaritzky, N., \& Califano, A. (2013). Optimization of rheological properties of gluten-free pasta dough using mixture Design. Journal of Cereal Science, 57(3), 520-526. http://dx.doi. org/10.1016/j.jcs.2013.03.003.

Larrosa, V., Lorenzo, G., Zaritzky, N., \& Califano, A. (2016). Improvement of the texture and quality of cooked gluten-free pasta. LebensmittelWissenschaft + Technologie, 70, 96-103. http://dx.doi.org/10.1016/j. lwt.2016.02.039.

Li, P. H., Huang, C. C., Yang, M. Y., \& Wang, C. C. R. (2012). Textural and sensory properties of salted noodles containing purple yam flour. Food Research International, 47(2), 223-228. http://dx.doi. org/10.1016/j.foodres.2011.06.035.

Limroongreungrat, K., \& Huang, Y.-W. (2007). Pasta products made from sweet potato fortified with soy protein. Lebensmittel-Wissenschaft + Technologie, 40(2), 200-206. http://dx.doi.org/10.1016/j.lwt.2005.09.012.

Lorusso, A., Verni, M., Montemurro, M., Coda, R., Gobbetti, M., \& Rizzello, C. G. (2017). Use of fermented quinoa flour for pasta making and evaluation of the technological and nutritional features. Lebensmittel-Wissenschaft + Technologie, 78, 215-221. http://dx.doi. org/10.1016/j.lwt.2016.12.046.

Lovera, M., Pérez, E., \& Laurentin, A. (2017). Digestibility of starches isolated from stem and root tubers of arracacha, cassava, cush-cush yam, potato and taro. Carbohydrate Polymers, 176, 50-55. http:// dx.doi.org/10.1016/j.carbpol.2017.08.049. PMid:28927626.
Mariotti, M., Iametti, S., Cappa, C., Rasmussen, P., \& Lucisano, M. (2011). Characterisation of gluten-free pasta through conventional and innovative methods: evaluation of the uncooked products. Journal of Cereal Science, 53(3), 319-327. http://dx.doi.org/10.1016/j. jcs.2011.02.001.

Marpalle, P., Sonawane, S. K., \& Arya, S. S. (2014). Effect of flaxseed flour addition on physicochemical and sensory properties of functional bread. Lebensmittel-Wissenschaft + Technologie, 58(2), 614-619. http://dx.doi.org/10.1016/j.lwt.2014.04.003.

Martínez, M. M., Rosell, C. M., \& Gómez, M. (2014). Modification of wheat flour functionality and digestibility through different extrusion conditions. Journal of Food Engineering, 143, 74-79. http://dx.doi. org/10.1016/j.jfoodeng.2014.06.035.

Martínez, M., Oliete, B., \& Gómez, M. (2013). Effect of the addition of extruded wheat flours on dough rheology and bread quality. Journal of Cereal Science, 57(3), 424-429. http://dx.doi.org/10.1016/j. jcs.2013.01.007.

Martínez-Mora, E. O. (2015). Caracterización morfológica y contenido de almidón resistente y disponible en bananos (Musa sapientum) exportables del Ecuador. Revista Española de Nutrición Humana y Dietética, 19(3), 153-159. http://dx.doi.org/10.14306/ renhyd.19.3.161.

Mirhosseini, H., Abdul Rashid, N. F., Amid, B. T., Cheong, K. W., Kazemi, M., \& Zulkurnain, M. (2015). Effect of partial replacement of corn flour with durian seed flour and pumpkin flour on cooking yield, texture properties, and sensory attributes of gluten free pasta. Lebensmittel-Wissenschaft + Technologie, 63(1), 184-190. http:// dx.doi.org/10.1016/j.lwt.2015.03.078.

Njintang, N. Y., Mbofung, C. M. F., Balaam, F., Kitissou, P., \& Scher, J. (2008). Effect of Taro (Colocasia esculenta) flour addition of the functional properties and alveographic wheat flour and dough. Journal of the Science of Food and Agriculture, 88(2), 273-279. http:// dx.doi.org/10.1002/jsfa.3085.

Odeku, O. A., Schmid, W., \& Picker-Freyer, K. M. (2008). Material and tablet properties of pregelatinized (thermally modified) Dioscorea starches. European Journal of Pharmaceutics and Biopharmaceutics, 70(1), 357-371. http://dx.doi.org/10.1016/j.ejpb.2008.04.011. PMid:18562187.

Onyango, C., Mutungi, C., Unbehend, G., \& Lindhauer, M. G. (2011). Modification of gluten-free sorghum batter and bread using maize, potato, cassava or rice starch. Lebensmittel-Wissenschaft + Technologie, 44(3), 681-686. http://dx.doi.org/10.1016/j.lwt.2010.09.006.

Osundahunsi, O. F., Seidu, K. T., \& Mueller, R. (2011). Dynamic rheological and physicochemical properties of annealed starches from two cultivars of cassava. Carbohydrate Polymers, 83(4), 19161921. http://dx.doi.org/10.1016/j.carbpol.2010.10.056.

Pu, H., Wei, J., Wang, L., Huang, J., Chen, X., Luo, C., Liu, S., \& Zhang, H. (2017). Effects of potato/wheat flours ratio on mixing properties of dough and quality of noodles. Journal of Cereal Science, 76, 236242. http://dx.doi.org/10.1016/j.jcs.2017.06.020.

Rafiq, A., Sharma, S., \& Singh, B. (2017). In vitro starch digestibility, degree of gelatinization and functional properties of twin screw prepared cereal-legume pasta. Journal of Cereal Science, 74, 279-287. http://dx.doi.org/10.1016/j.jcs.2017.03.001.

Rodríguez-Miranda, J., Ruiz-López, I. I., Herman-Lara, E., MartínezSánchez, C. E., Delgado-Licon, E., \& Vivar-Vera, M. A. (2011). Development of extruded snacks using taro (Colocasia esculenta) and nixtamalized maize (Zea mays) flour blends. LebensmittelWissenschaft + Technologie, 44(3), 673-680. http://dx.doi.org/10.1016/j. lwt.2010.06.036. 
Sharma, P., \& Gujral, H. S. (2014). Cookie making behavior of wheat-barley flour blends and effects on antioxidant properties. Lebensmittel-Wissenschaft + Technologie, 55(1), 301-307. http:// dx.doi.org/10.1016/j.lwt.2013.08.019.

Shiau, S. Y., Wu, M. Y., \& Liu, Y. L. (2015). The effect of pineapple core fiber on dough rheology and the quality of mantou. Yao Wu Shi Pin Fen Xi, 23(3), 493-500. http://dx.doi.org/10.1016/j.jfda.2014.10.010. PMid:28911708.

Struck, S., Straube, D., Zahn, S., \& Rohm, H. (2018). Interaction of wheat macromolecules and berry pomace in model dough: rheology and microstructure. Journal of Food Engineering, 223, 109-115. http:// dx.doi.org/10.1016/j.jfoodeng.2017.12.011.

Tadapaneni, R. K., Yang, R., Carter, B., \& Tang, J. (2017). A new method to determine the water activity and the net isosteric heats of sorption for low moisture foods at elevated temperatures. Food Research International, 102, 203-212. http://dx.doi.org/10.1016/j. foodres.2017.09.070. PMid:29195941.

Tazrart, K., Zaidi, F., Lamacchia, C., \& Haros, M. (2016). Effect of durum wheat semolina substitution with broad bean flour (Vicia faba) on the Maccheronccini pasta quality. European Food Research and Technology, 242(4), 477-485. http://dx.doi.org/10.1007/s00217-015-2558-z.

Tortoe, C., Johnson, P. N. T., \& Nyarko, A. I. (2009). Effects of osmodehydration, blanching and semi-ripening on the viscoelastic, water activity and colorimetry properties of flour from three cultivars of plantain (Musa AAB). Innovative Food Science \& Emerging Technologies, 10(1), 82-86. http://dx.doi.org/10.1016/j.ifset.2008.08.003.
Witczak, M., Juszczak, L., Ziobro, R., \& Korus, J. (2012). Influence of modified starches on properties of gluten-free dough and bread. Part I: rheological and thermal properties of gluten-free dough. Food Hydrocolloids, 28(2), 353-360. http://dx.doi.org/10.1016/j. foodhyd.2012.01.009.

Xing-Li, L., Tai-hua, M., Hong-nan, S., Miao, Z., \& Jing-wang, C. (2016). Influence of potato flour on dough rheological properties and quality of steamed bread. Journal of Integrative Agriculture, 15(11), 26662676. http://dx.doi.org/10.1016/S2095-3119(16)61388-6.

Yadav, B. S., Yadav, R. B., Kumari, M., \& Khatkar, B. S. (2014). Studies on suitability of wheat flour blends with sweet potato, colocasia and water chestnut flours for noodle making. LebensmittelWissenschaft + Technologie, 57(1), 352-358. http://dx.doi. org/10.1016/j.lwt.2013.12.042.

Zardetto, S., \& Dalla Rosa, M. (2009). Effect of extrusion process on properties of cooked, fresh egg pasta. Journal of Food Engineering, 92(1), 70-77. http://dx.doi.org/10.1016/j.jfoodeng.2008.10.027.

Zavareze, E. R., \& Dias, A. R. G. (2011). Impact of heat-moisture treatment and annealing in starches: a review. Carbohydrate Polymers, 83(2), 317-328. http://dx.doi.org/10.1016/j. carbpol.2010.08.064.

Zhao, X., Andersson, M., \& Andersson, R. (2018). Resistant starch and other dietary fiber components in tubers from a high amylose potato. Food Chemistry, 251, 58-63. http://dx.doi.org/10.1016/j. foodchem.2018.01.028. PMid:29426424. 